\title{
Primary Intraosseous Squamous Cell Carcinoma Derived From Odontogenic Cyst
}

National Cancer Institute

\section{Source}

National Cancer Institute. Primary Intraosseous Squamous Cell Carcinoma Derived From

Odontogenic Cyst. NCI Thesaurus. Code C7500.

A rare squamous cell carcinoma that arises centrally from the jaw from the lining of an odontogenic cyst. 